\title{
Is Job Redundancy Applied Right?
}

\section{Munshi Joy*}

Department of Business Management and Strategy, American Institute of Management Science, Richardson, United States

\begin{abstract}
Job redundancy is the termination of a position, not an employee. It has recently gained its popularity among MNEs as a cost-cutting and profit enhancing strategy. While this should be considered as the last resort to downsize, studies suggest that businesses adapt redundancy without even considering other available strategic option, whenever they face financial difficulties. During and followed by the recent credit crunch, MNEs around the world especially those operating in the the UK and Australia has frequently announced redundancy. However, the practice is often criticised by the critics in that the strategy is often used to cut heads, not jobs. Therefore, the researcher has critically analysed job redundancy from academic, business and ethical viewpoints.
\end{abstract}

Keywords: Redundancy; Job; Employee; Strategy

\section{Introduction}

The number of redundancies has been consistently rising in many countries around the world including the UK and Australia. A recent report confirms that over $40 \%$ of Australian jobs are at risk [1] while by 2025 more than five million Australians will become jobless due to redundancy, while at least 1 million Australian will be redundant by 2020 [2]. Redundancy is in fact a widely practiced strategy by enterprises and business-entities for downsizing, cost-cutting, rejuvenating or even coping with new technology [3]. While there is situation that compel firms to use redundancy as a last resort [3], it is evident that with the rise in redundancy announcements during the last four decades, the strategy is often used to cut heads, rather than terminating the positions $[4,5]$. Therefore, questions may arise whether job redundancy is applied right, or the strategy is simply used as a tool to cut heads - in other words, being abused.

\section{Discussion}

Undoubtedly, job redundancy refers to the situation where an employer terminates a position, not simply an employee [6,7]. However, it is often found in corporate offices, businesses, and even government offices that there are significant numbers of workstations that are empty, and notes read 'position vacant', which sometimes hinder the operations of the organisations [8]. While the organisations may explain the situation to be a temporary one, or has resulted from unavailability of the right candidate, or these jobs are no longer required [9], this strengthens the fact that redundancies are used to cut heads, not costs or downsize [10]. This, on the other hand, poses twofold risks to organisations. First, it breaks down the value chain of the firm, which ultimately pushes them to lose their core competence, ultimately and market leadership [11,12]. Secondly, the amount of compensation going with such unfair dismissals turns to be even more than keeping those redundant staff $[7,13]$.

\section{Conclusion}

Therefore, it is high time for businesses to re-evaluate their so called 'costly strategy to cut cost', and make sure they apply redundancy right.

\section{References}

1. Florence L, Partland L (2015) Almost 40 per cent pf Australian jobs could be replaced by technology by 2015 , report finds.

2. Mc Cauley D (2017) Australians need to 'wake up' to the robot threat, with five million jobs at risk: Futurist Shara Evans, Australia.

3. Redman T, Wilkinson A, Dundon T (2017) Contemporary human resource management: Text and cases ( $5^{\text {th }}$ Eds). Pearson Education Limited, UK.

4. Towell N (2015) Redundancy: Defence department's redundancy hit list, Australia.

5. Oam MS, Punch P (2017) Thinking of downsizing your workforce? Make sure you get the consultation process right-or the "Redundancies" could turn out to be unfair dismissals.

6. Pilbeam S, Corbridge M (2010) People resourcing and talent management: Contemporary HRM in practice $\left(4^{\text {th }}\right.$ Eds). Financial Times Prentice Hall 2: 1.

7. Foot $M$, Hook $C$ (2015) Introducing human resource management ( $7^{\text {th }}$ Eds). Pearson Education Ltd, UK.

8. Gandolfi F, Hansson M (2010) Reduction-in-force (RIF) New developments and a brief historical analysis of a business strategy. J Manage Organ 16: 727-743.

9. Fair Work Commission (2018) Job no longer required due to changes in operational requirements, Australia.

10. HRD (2009) Cut costs, not heads: 5 strategies to prepare for the upturn Australia.

11. Mc Grath RG (2009) A better way to cut cost. Harvard Business Review 2: 1.

12. Wearden $G$ (2010) Unemployment breaks through 2.5 million.

13. Fair Work Ombudsman (2018) Company Director fined almost $\$ 50,000$ for ignoring unfair dismissal compensation order, Australia.

*Corresponding author: Munshi Joy, Department of Business Management and Strategy, American Institute of Management Science, Richardson TX 75080, United States, Tel: + 1-214-884-865; E-mail: joy.munshi@aimsawards.org

Received June 05, 2018; Accepted June 09, 2018; Published June 20, 2018

Citation: Joy M (2018) Is Job Redundancy Applied Right? Review Pub Administration Manag 6: 248. doi:10.4172/2315-7844.1000248

Copyright: () 2018 Joy M. This is an open-access article distributed under the terms of the Creative Commons Attribution License, which permits unrestricted use, distribution, and reproduction in any medium, provided the original author and source are credited. 